\title{
Urticarial vasculitis coexisting with primary myelofibrosis - a case report
}

\section{Pokrzywka naczyniowa współistniejąca z pierwotnym włóknieniem szpiku - opis przypadku}

\author{
Radomir Reszke', Adam Reich ${ }^{1,2}$ \\ 'Department of Dermatology, Venereology and Allergology, Medical University of Wroclaw, Poland \\ 2Department of Dermatology, University of Rzeszow, Poland \\ 'Katedra i Klinika Dermatologii, Wenerologii i Alergologii Uniwersytetu Medycznego we Wrocławiu, Polska \\ 2Zakład i Klinika Dermatologii Uniwersytetu Rzeszowskiego, Polska
}

\section{CORRESPONDING AUTHOR/ ADRES DO KORESPONDENCJI:} lek. Radomir Reszke Katedra i Klinika Dermatologii, Wenerologii i Alergologii ul. Chałubińskiego 1 50-368 Wrocław, Polska tel.: +48 713270941 faks: +48713270942 e-mail: r.reszke@op.pl

\begin{abstract}
Introduction. Urticarial vasculitis is a subtype of cutaneous leukocytoclastic vasculitis. The disease often accompanies systemic disorders, including hematologic malignancies, connective tissue diseases, and infectious diseases, or may be drug-induced.

Case report. A 69-year-old man with an established diagnosis of primary myelofibrosis was admitted to our department because of severe pruritus and cutaneous urticarial lesions. At the time of admission the patient was not receiving treatment for the underlying hematologic disease. Upon physical examination diffuse and confluent firm urticarial lesions were observed on the trunk and limbs. A skin biopsy revealed histological features of urticarial vasculitis. We initiated intravenous hydrocortisone up to $400 \mathrm{mg}$ / day, methylprednisolone $500 \mathrm{mg}$ in a single dose and prednisone orally $20 \mathrm{mg} /$ day, with rapid resolution of skin lesions.

Conclusions. Urticarial vasculitis may accompany various systemic disorders, including primary myelofibrosis. To our knowledge this is the second case in the literature of urticarial vasculitis associated with myelofibrosis. Treatment with systemic glucocorticosteroids should be considered, as this method is usually beneficial.
\end{abstract}

\section{STRESZCZENIE}

Wprowadzenie. Pokrzywka naczyniowa jest rodzajem leukocytoklastycznego zapalenia naczyń. Często towarzyszy schorzeniom układowym, w tym nowotworom hematologicznym, układowym chorobom tkanki łącznej, lub może mieć etiologię polekową.

Opis przypadku. Mężczyzna 69-letni z rozpoznaniem samoistnego włóknienia szpiku został przyjęty do kliniki z powodu nasilonego świądu trwającego od 9 miesięcy oraz występujących od ok. 2 miesięcy zmian pokrzywkowatych. Pacjent nie otrzymywał leczenia $\mathrm{z}$ powodu choroby hematologicznej. $\mathrm{W}$ badaniu przedmiotowym przy przyjęciu stwierdzono rozsiane i zlewne zmiany pokrzywkowate zlokalizowane na tułowiu i kończynach, spoiste $\mathrm{w}$ badaniu palpacyjnym. Badanie 
histopatologiczne wycinka ze zmiany skórnej potwierdziło rozpoznanie pokrzywki naczyniowej. W leczeniu zastosowano dożylnie hydrokortyzon w dawce do $400 \mathrm{mg} /$ dobę, metyloprednizolon w dawce $500 \mathrm{mg}$ jednorazowo, a następnie prednizon doustnie w dawce $20 \mathrm{mg}$ / dobę. Uzyskano szybkie ustąpienie zmian skórnych.

Wnioski. Pokrzywka naczyniowa może towarzyszyć wielu schorzeniom układowym, w tym samoistnemu włóknieniu szpiku. Zgodnie z wiedzą autorów jest to drugi przypadek pokrzywki naczyniowej związanej z włóknieniem szpiku. W leczeniu należy rozważyć zastosowanie systemowej kortykosteroidoterapii, gdyż ta metoda przynosi zwykle korzystne efekty w zakresie zmian skórnych.

Key words: urticarial vasculitis, myelofibrosis, prednisone, itch.

Słowa kluczowe: pokrzywka naczyniowa, włóknienie szpiku, prednizon, świąd.

\section{INTRODUCTION}

According to the classification of the World Health Organization (WHO) concerning myeloid neoplasms, myeloproliferative neoplasms encompass chronic myeloid leukemia, chronic neutrophilic leukemia, polycythemia vera, essential thrombocytopenia (ET), primary myelofibrosis (PMF), chronic eosinophilic leukemia (not otherwise specified), mastocytosis and unclassifiable myeloproliferative neoplasms [1]. Among PMF, prefibrotic stage and overt fibrotic stage are mentioned. Primary myelofibrosis is characterized by stem cell-derived clonal myeloproliferation and presence of somatic mutations (mostly JAK2 or $C A L R$ ), along with reactive bone marrow fibrosis, osteosclerosis, angiogenesis, extramedullary hematopoiesis, and abnormal cytokine expression [2]. From the clinical point of view, severe anemia, fatigue, night sweats, fever, cachexia, bone pain, hepatosplenomegaly, splenic infarct, pruritus, thrombotic and bleeding events may occur [2].

Urticarial vasculitis is a subtype of cutaneous leukocytoclastic vasculitis presenting with urticarial cutaneous lesions along with other distinct clinical, histologic, and immunologic features of vasculitis [3]. Severe forms of urticarial vasculitis may also be associated with musculoskeletal, pulmonary, renal, gastrointestinal, cardiovascular and ophthalmologic symptoms [3]. Autoimmune connective tissue diseases (CTD), complement deficiency, viral infections, serum sickness, hematologic disorders, adverse drug reactions and sun exposure have been reported to be associated with urticarial vasculitis onset [4]. However, up to $70 \%$ of cases may be idiopathic [5].

\section{WPROWADZENIE}

Zgodnie z opracowaną przez Światową Organizację Zdrowia (World Health Organization - WHO) klasyfikacją nowotworów układu krwiotwórczego nowotwory mieloproliferacyjne obejmują: przewlekłą białaczkę szpikową, przewlekłą białaczkę neutrofilową, czerwienicę prawdziwą, nadpłytkowość samoistną (essential thrombocytopenia - ET), pierwotne włóknienie szpiku (primary myelofibrosis - PMF), przewlekłą białaczkę eozynofilową (bliżej nieokreśloną), mastocytozę oraz niesklasyfikowane nowotwory mieloproliferacyjne [1]. W przebiegu PMF wyróżnia się dwie fazy: przedwłóknieniową oraz zwłóknieniową. Istotą PMF jest mieloproliferacja klonalna komórek macierzystych oraz obecność mutacji somatycznych (głównie JAK2 lub CALR). Chorobie towarzyszy odczynowe włóknienie szpiku, zmiany osteosklerotyczne kości, angiogeneza, hematopoeza pozaszpikowa oraz nieprawidłowa ekspresja cytokin [2]. W przebiegu PMF może występować szereg objawów klinicznych, takich jak ciężka niedokrwistość, zmęczenie, nocne poty, gorączka, wyniszczenie, bóle kostne, powiększenie wątroby i śledziony, zawał śledziony, świąd oraz zaburzenia zakrzepowo-krwotoczne [2].

Pokrzywka naczyniowa jest podtypem leukocytoklastycznego zapalenia naczyń. Charakteryzuje się obecnością pokrzywkowatych zmian skórnych, którym towarzyszy obraz kliniczny, histologiczny i immunologiczny typowy dla zapalenia naczyń [3]. W ciężkich postaciach pokrzywki naczyniowej mogą również występować objawy ze strony układu mięśniowo-szkieletowego, płuc, nerek, układu pokarmowego, układu krążenia oraz narządu wzroku [3]. W piśmiennictwie 


\section{OBJECTIVE}

The objective of this report was to describe a case of an elderly man, who suffered from urticarial vasculitis associated with PMF.

\section{CASE REPORT}

A 69-year-old man was admitted to our department in March 2017 due to skin lesions that had appeared approximately 2 months earlier. According to the patient's report, single lesions were present on the skin for more than 24 hours since their appearance. Additionally, the patient complained of severe, generalized pruritus that had lasted for 9 months. Topical corticosteroids, second generation antihistamines and gabapentin had not resulted in any reduction of these symptoms. Concerning the underlying disease, PMF was diagnosed in 2014 (JAK2 and BCR-ABL mutations were absent). Previous treatment modalities encompassed hydroxyurea (between December 2015 and February 2016), thalidomide (between February 2016 and April 2016) and mercaptopurine (between May 2016 and December 2016). The treatment was then discontinued, as PMF was clinically stable. In addition, the patient suffered from arterial hypertension, mild mitral and tricuspid regurgitation, hyperuricemia, renal cysts and chronic obstructive pulmonary disease associated with his occupation (copper miner) and smoking. He also had a history of pulmonary thrombosis. The patient's medications included carvedilol (6.25 mg/day), furosemide (20 mg/day), enoxaparin ( $80 \mathrm{mg} /$ day) and zolpidem (10 mg/day).

Upon physical examination, disseminated urticarial lesions with firm structure were observed on the trunk and proximal aspects of all extremities (figs. 1-3). The patient considered pruritus as of the worst imaginable severity - 10/10 according to the Numerical Rating Scale (NRS). Palpation revealed prominent splenomegaly ( $4 \mathrm{~cm}$ below the umbilicus) and hepatomegaly. These organs measured $20.6 \mathrm{~cm}$ in bipolar diameter, and $15.9 \mathrm{~cm}$ in antero-posterior diameter according to abdominal ultrasonography, respectively. Laboratory examinations revealed mild anemia ( $\mathrm{Hb} 12.4 \mathrm{~g} / \mathrm{dl}$ ) with the presence of circulating polychromatophilic erythroblasts, anisocytosis, poikilocytosis and dacrocytes (erythrocytes resembling teardrops) in manual blood count. Additionally, elevated levels of urea (68 mg/dl, reference norm: $18-55 \mathrm{mg} / \mathrm{dl}$ ), creatinine (1.51 mg/dl, reference norm: 0.73-1.18 mg/dl), uric acid (16 mg/dl, reference norm: 3.5-7.2 mg/dl), and serum activity of lactate dehydrogenase $(396 \mathrm{U} / 1$, reference norm: 125-220 U/1) were observed, whereas the concentrations of the $\mathrm{C} 3$ complement component $(0.456 \mathrm{~g} / 1)$, immunoglobulin M (0.193 g/l) and $\kappa$ light chains $(1.44 \mathrm{~g} / \mathrm{l})$ were decreased. Serum levels of C1 opisano występowanie pokrzywki naczyniowej z układowymi chorobami tkanki łącznej o podłożu autoimmunologicznym, niedoborem dopełniacza, zakażeniami wirusowymi, chorobą posurowiczą, schorzeniami hematologicznymi, w przebiegu reakcji polekowych oraz po ekspozycji na promieniowanie słoneczne [4]. W 70\% przypadków pokrzywka naczyniowa ma jednak charakter idiopatyczny [5].

\section{CEL PRACY}

Celem pracy było przedstawienie przypadku mężczyzny w podeszłym wieku, u którego rozpoznano pokrzywkę naczyniową $\mathrm{w}$ przebiegu pierwotnego zwłóknienia szpiku.

\section{OPIS PRZYPADKU}

Mężczyzna 69-letni został przyjęty do kliniki w marcu 2017 r. z powodu wykwitów skórnych, które pojawiły się ok. 2 miesięcy wcześniej. Według pacjenta pojedyncze zmiany utrzymywały się na skórze przez ponad 24 godziny od wystąpienia. Pacjent zgłosił również ciężki uogólniony świąd trwający od 9 miesięcy. Leczenie miejscowe glikokortykosteroidami oraz terapia lekami przeciwhistaminowymi drugiej generacji i gabapentyną nie przyniosły poprawy. U chorego w 2014 r. rozpoznano pierwotne włoknienie szpiku (nie stwierdzono mutacji JAK2 ani BCR-ABL). W leczeniu stosowano hydroksymocznik (od grudnia 2015 do lutego 2016 r.), talidomid (od lutego 2016 do kwietnia 2016 r.) oraz merkaptopurynę (od maja 2016 do grudnia 2016 r.). Leczenie odstawiono ze względu na kliniczną stabilizację PMF. U pacjenta występowały ponadto: nadciśnienie tętnicze, łagodna niedomykalność zastawki mitralnej i trójdzielnej, hiperurykemia, torbiele nerek oraz przewlekła obturacyjna choroba płuc związana z wykonywanym zawodem (praca w kopalni miedzi) oraz paleniem tytoniu. W wywiadzie stwierdzono także zatorowość płucną. Pacjent przyjmował karwedilol (6,25 mg/dobę), furosemid (20 mg/dobę), enoksaparynę ( $80 \mathrm{mg} /$ dobę) i zolpidem (10 mg/dobę).

$\mathrm{W}$ badaniu przedmiotowym stwierdzono rozsiane bąble pokrzywkowe o spoistej konsystencji, zlokalizowane na tułowiu i bliższych częściach kończyn (ryc. 1-3). W skali numerycznej (NRS) pacjent określił stopień nasilenia świądu jako najgorszy, jaki można sobie wyobrazić (10/10). Palpacyjnie stwierdzono wyraźne powiększenie śledziony (4 cm poniżej pępka) oraz powiększenie wątroby. W USG jamy brzusznej wielkość tych narządów określono odpowiednio jako 20,6 cm w wymiarze dwubiegunowym oraz 15,9 cm w wymiarze przednio-tylnym. Wyniki badań laboratoryjnych wykazały łagodną niedokrwistość (Hb 12,4 g/ dl), a w rozmazie ręcznym stwierdzono obecność krążących erytroblastów wielobarwliwych i dakrocytów 


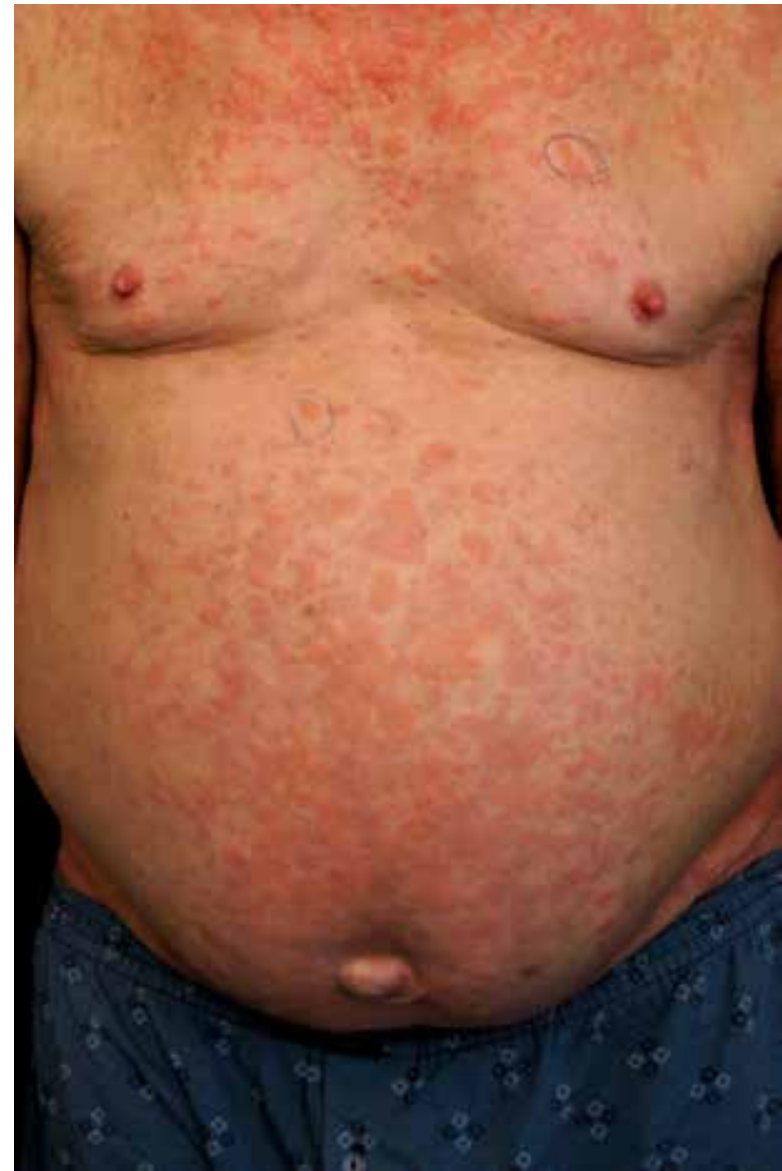

Figure I. Widespread urticarial lesions on the trunk (some lesions were circled to observe the resolution time)

Rycina I. Rozsiane zmiany pokrzywkowe na tułowiu (wybrane zmiany otoczono obwódkq w celu oceny czasu ich utrzymywania się na skórze)

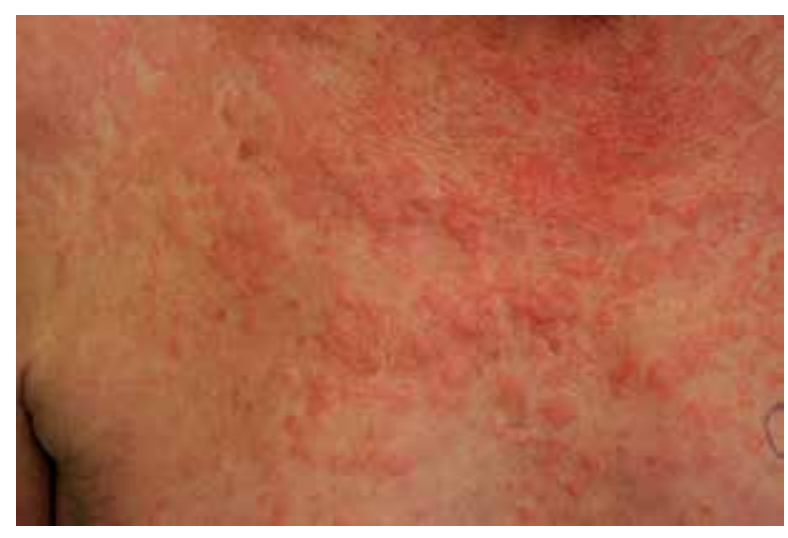

Figure 2. Close-up of the lesions on the chest

Rycina 2. Zmiany skórne na klatce piersiowej (w powiększeniu)

esterase inhibitor, rheumatoid factor (RF), antinuclear antibodies (ANA), perinuclear anti-neutrophil cytoplasmic antibodies (ANCA), cytoplasmic ANCA and anti-C1q antibodies were within normal limits or absent. Chest X-ray, densitometry of the lumbar spine

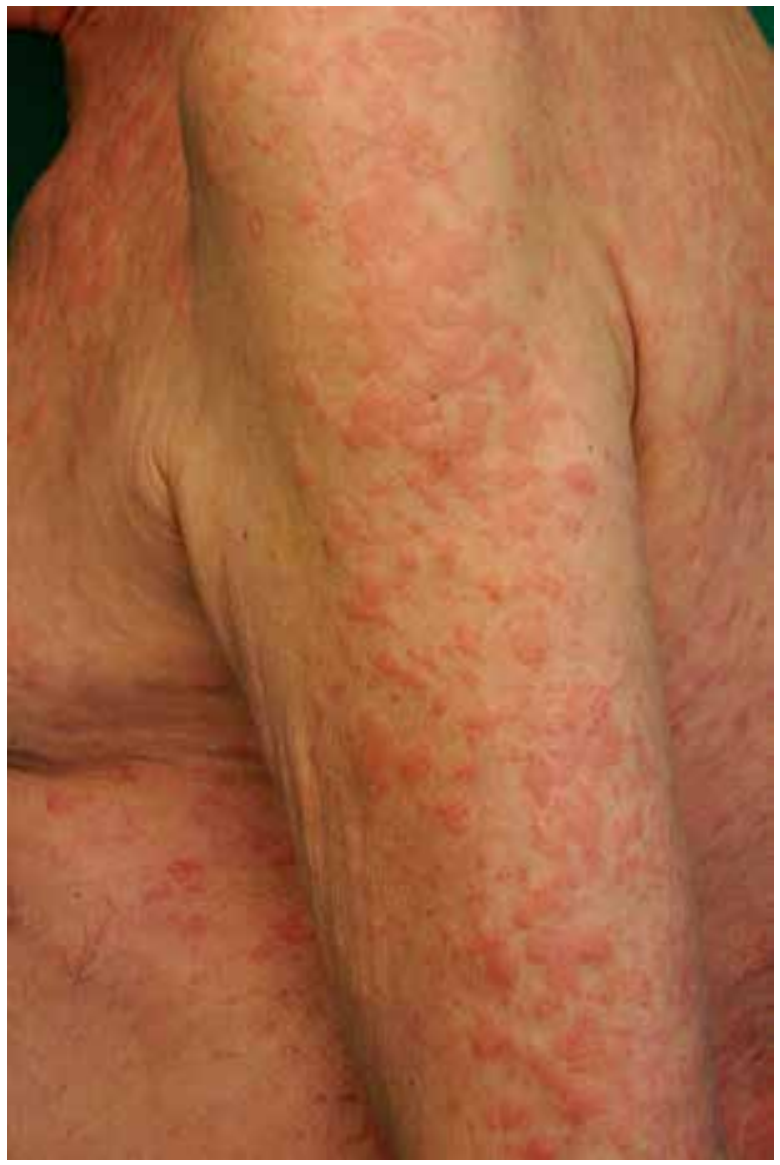

Figure 3. Urticarial wheals present on the left arm

Rycina 3. Bąble pokrzywkowe zlokalizowane na lewym ramieniu

(erytrocytów w kształcie kropli łzy), a także anizocytozę i poikilocytozę. Odnotowano również podwyższone stężenie mocznika $(68 \mathrm{mg} / \mathrm{dl}$, wartości referencyjne: $18-55 \mathrm{mg} / \mathrm{dl})$, kreatyniny $(1,51 \mathrm{mg} / \mathrm{dl}$, wartości referencyjne: 0,73-1,18 mg/dl), kwasu moczowego (16 mg/dl, wartości referencyjne: 3,5-7,2 mg/dl) oraz dehydrogenazy mleczanowej w surowicy (396 U/1, wartości referencyjne: 125-220 U/1). Stężenia składowej C3 dopełniacza (0,456 g/1), immunoglobuliny M $(0,193 \mathrm{~g} / 1)$ oraz łańcuchów lekkich $\kappa(1,44 \mathrm{~g} / 1)$ były natomiast obniżone. Oznaczone w surowicy poziomy inhibitora esterazy C1, czynnika reumatoidalnego (RF), przeciwciał przeciwjądrowych (ANA), przeciwciał przeciwko cytoplazmie neutrofilów (ANCA) typu okołojądrowego, przeciwciał ANCA typu cytoplazmatycznego i przeciwciał anty-C1q mieściły się w granicach normy lub były ujemne. $\mathrm{W}$ badaniu rentgenograficznym (RTG) klatki piersiowej, densytometrii odcinka lędźwiowego kręgosłupa, a także badaniu USG żył i tętnic kończyn dolnych nie stwierdzono klinicznie istotnych nieprawidłowości. Konsultujący hemato$\log$ zalecił allopurynol (300 mg/dobę). Na podstawie konsultacji psychiatrycznej rozpoznano organiczne zaburzenie nastroju i wdrożono leczenie mirtazapiną 
and lower leg arterial and venous ultrasonography did not demonstrate clinically significant pathologies. The consulting hematologist recommended allopurinol (300 mg/day). Based on the psychiatric consultation, organic mood disorder was diagnosed and mirtazapine $15 \mathrm{mg} /$ day was introduced with subsequent dose elevation to $30 \mathrm{mg} /$ day 1 week later. A skin biopsy was taken from the urticarial lesions. No immunoglobulin or complement deposits were observed in the direct immunofluorescence examination (DIF), whereas histological examination revealed diffuse and perivascular infiltrates composed of lymphocytes, histiocytes, neutrophils and eosinophils, along with local erythrocyte extravasation. Moreover, scarce mast cells were observed after performing toluidine and tryptase stains. Based on the clinical picture and additional investigations urticarial vasculitis was diagnosed and treatment consisting of hydrocortisone up to $400 \mathrm{mg} /$ day intravenously for 3 days, methylprednisolone $500 \mathrm{mg}$ intravenously in a single dose, followed by prednisone $20 \mathrm{mg} / \mathrm{d}$ orally, was introduced. Additional treatments comprised hydroxyzine up to $45 \mathrm{mg} /$ day, ibuprofen $400 \mathrm{mg}$ / day, omeprazole $20 \mathrm{mg} /$ day, potassium supplementation and cooling ointment applied three times daily.

At the end of the hospitalization ( $12^{\text {th }}$ day) skin lesions were still present, although less prominent. At the follow-up visit a month later the lesions had disappeared entirely (without the presence of postinflammatory hyperpigmentation or petechiae), but pruritus persisted and still was quite severe (NRS 7/10). Skin scrapings followed by microscopic examination did not reveal any ectoparasites. Mirtazapine was switched to escitalopram ( $5 \mathrm{mg} /$ day), while the prednisone dose was reduced to $15 \mathrm{mg} /$ day. Pruritus intensity lessened over the course of 4 weeks. Unfortunately, the patient died 6 weeks later due to cardiac arrest.

\section{DISCUSSION}

The annual incidence of myelofibrosis in the European Union was estimated as 0.1 per 100000 to 1 per 100000 [6]. According to the WHO diagnostic criteria published in 2016, overt PMF may be diagnosed based on the presence of 3 major criteria and at least 1 minor criterion [1]. Major criteria include: (1) the presence of megakaryocytic proliferation with atypia (accompanied by either reticulin and/or collagen fibrosis of grade 2 or 3), (2) inability to meet WHO criteria for ET, PV, CML (BCR-ABL positive), myelodysplastic syndromes or other myeloid neoplasms; and (3) presence of JAK2, CALR or MPL mutation. If the latter is not present, presence of another clonal marker or absence of reactive myelofibrosis has to be proven. Minor criteria include anemia (not attributed w dawce 15 mg/dobę, którą zwiększono do 30 mg/ dobę w kolejnym tygodniu. Pobrano wycinek skóry z okolicy zmian pokrzywkowych. W bezpośrednim badaniu immunofluorescencyjnym nie stwierdzono złogów immunoglobulin ani składowych dopełniacza. W badaniu histopatologicznym wykazano obecność rozlanych i okołonaczyniowych nacieków złożonych z limfocytów, histiocytów, neutrofilów i eozynofilów, jak również miejscowe wynaczynienie erytrocytów. W barwieniu błękitem toluidynowym i reakcji tryptazy zaobserwowano ponadto nieliczne mastocyty. Na podstawie obrazu klinicznego oraz badań dodatkowych rozpoznano pokrzywkę naczyniową. Wdrożono leczenie hydrokortyzonem dożylnie w dawce do $400 \mathrm{mg} /$ dobę przez 3 dni oraz metyloprednizolonem dożylnie w pojedynczej dawce $500 \mathrm{mg}$, a następnie prednizonem doustnie w dawce $20 \mathrm{mg} /$ dobę. Dodatkowo zalecono hydroksyzynę w dawce do $45 \mathrm{mg} /$ dobę, ibuprofen $400 \mathrm{mg} /$ dobę, omeprazol $20 \mathrm{mg} /$ dobę, suplementację potasem oraz maść chłodzącą na skórę do stosowania 3 razy dziennie.

Pod koniec hospitalizacji (w 12. dobie) zmiany skórne były nadal obecne, choć mniej nasilone. Podczas wizyty kontrolnej w kolejnym miesiącu stwierdzono całkowite ustąpienie zmian skórnych (bez przebarwień pozapalnych i wybroczyn), jednak świąd utrzymywał się i był nadal dość nasilony (7/10 w skali NRS). W badaniu mikroskopowym zeskrobin skórnych nie wykazano obecności ektopasożytów. Mirtazapinę zamieniono na escitalopram (5 mg/dobę), a dawkę prednizonu zmniejszono do $15 \mathrm{mg} /$ dobę. Nasilenie świądu zmniejszyło się w czasie kolejnych 4 tygodni. Pacjent zmarł 6 tygodni później z powodu nagłego zatrzymania krążenia.

\section{OMÓWIENIE}

Szacowany roczny współczynnik zapadalności na włóknienie szpiku w Unii Europejskiej mieści się w przedziale od 0,1 do 1 przypadku na 100000 [6]. Zgodnie z kryteriami diagnostycznymi WHO opublikowanymi w 2016 r. rozpoznanie PMF można ustalić na podstawie stwierdzenia 3 kryteriów większych i co najmniej 1 kryterium mniejszego [1]. Kryteria większe obejmują: 1) proliferację i atypię megakariocytów (z włóknieniem retikulinowym i/lub kolagenowym stopnia 2. lub 3.), 2) niespełnienie kryteriów WHO dla ET, PV, CML (BCR-ABL-dodatniej), zespołów mielodysplastycznych bądź innych nowotworów mieloidalnych oraz 3) wykazanie obecności mutacji JAK2, CALR lub MPL. W przypadku ich braku należy stwierdzić obecność innego markera klonalności lub wykluczyć odczynowe włóknienie szpiku. Kryteria mniejsze obejmują: niedokrwistość (niezwiązaną z chorobami współistniejącymi), leukocytozę (> $\left.11 \times 10^{3} / 1\right)$, stwierdzaną palpacyjnie splenomegalię oraz leukoerytroblastyczny 
to comorbidities), leucocytosis $\left(>11 \times 10^{3} / 1\right)$, palpable splenomegaly and leukoerythroblastosis [1]. Marked constitutional symptoms, such as fatigue, night sweats, fever, weight loss, pruritus and problems arising from hepatosplenomegaly may severely impair the quality of life of patients with myelofibrosis [7]. The median survival for symptomatic myelofibrosis patients after establishing the diagnosis is approximately 2-5 years [6].

Urticaria is a disease characterized by the development of wheals, angioedema or both of these symptoms [8]. Typical features of an urticarial wheal include the development of central swelling, with variable size, surrounded by a reflex erythema; association with pruritus, occasionally with burning sensation; and fleeting nature of the lesions meaning that they subside usually within 1-24 hours. However, urticaria-like lesions and/or angioedema may also be a symptom of other diseases or syndromes including maculopapular cutaneous mastocytosis, bradykinin-mediated angioedema (such as hereditary angioedema), exercise-induced anaphylaxis, cryopyrin-associated periodic syndromes, Schnitzler's syndrome, Gleich's syndrome, and Wells's syndrome, as well as urticarial vasculitis [8]. Diagnostic features of urticarial vasculitis include idiopathic urticarial lesions of chronic nature that present with vessel damage and last for longer than 24 hours, leukocytoclastic vasculitis on histology, lesions of purpuric or erythemamultiforme nature, clinical signs of multisystem disease, laboratory changes, resistance to therapy with antihistamines and serologic evidence of CTD [9]. The pathogenesis of urticarial vasculitis is associated with the type III hypersensitivity reaction similarly to other types of leukocytoclastic vasculitis; the circulating immune complexes supporting this hypothesis are detected in about $30 \%$ to $75 \%$ of patients [4]. Most commonly, the disease occurs in young or middle-aged women [3]. Although the lesions may be accompanied by pruritus (which is obviously typical for the spectrum of urticaria), urticarial vasculitis patients more often describe the accompanying sensations of burning or pain. Patients with urticarial vasculitis may be categorized as those with hypocomplementemia (hypocomplementemic urticarial vasculitis - HUVS) and those with normal complement levels (normocomplementemic urticarial vasculitis NUVS), the former being more susceptible to present along with systemic involvement [4]. Extracutaneous involvement has multiple possible manifestations from various organs. Joints may be affected in $75 \%$ of cases, presenting with arthralgia, swelling, stiffness or arthritis affecting single or multiple joints [9]. Renal, respiratory, ocular, gastrointestinal and nervous symptomatology affects about $60 \%, 55 \%, 35 \%, 30 \%$ and $12 \%$ of patients, respectively. obraz krwi [1]. Nasilone objawy ogólnoustrojowe, takie jak zmęczenie, nocne poty, gorączka, redukcja masy ciała, a także świąd i dolegliwości wywoływane hepatosplenomegalią, mogą znacząco obniżać jakość życia pacjentów z włóknieniem szpiku [7]. Mediana przeżycia u pacjentów z objawowym włóknieniem szpiku po ustaleniu rozpoznania wynosi ok. 2-5 lat [6].

W przebiegu pokrzywki dochodzi do wysiewu bąbli, obrzęku naczynioruchowego lub obu tych objawów [8]. Charakterystyczny dla bąbli pokrzywkowych jest różnej wielkości obrzęk części centralnej, który otacza rumieniowa obwódka. Typowe dla choroby są także występowanie świądu, któremu może towarzyszyć uczucie pieczenia, oraz przemijający charakter bąbli pokrzywkowych (zazwyczaj ustępują w ciągu 1-24 godzin). Jednak zmiany pokrzywkowe i/lub obrzęk naczynioruchowy mogą występować w przebiegu innych chorób lub zespołów chorobowych, m.in. mastocytozy skórnej plamisto-grudkowej, obrzęku naczynioruchowego mediowanego bradykininą (np. wrodzonego obrzęku naczynioruchowego), anafilaksji wywołanej wysiłkiem fizycznym, okresowych zespołów zależnych od białka kriopiryny, zespołu Schnitzlera, zespołu Gleicha i zespołu Wellsa, jak również pokrzywki naczyniowej [8]. Wśród cech diagnostycznych pokrzywki naczyniowej należy wymienić: przewlekłe zmiany pokrzywkowe o charakterze idiopatycznym przebiegające z uszkodzeniem naczyń i utrzymujące się dłużej niż przez 24 godziny, leukocytoklastyczne zapalenie naczyń w obrazie histopatologicznym, zmiany o charakterze plamicy lub rumienia wielopostaciowego, objawy kliniczne choroby wieloukładowej, odchylenia w badaniach laboratoryjnych, oporność na leczenie przeciwhistaminowe i cechy serologiczne chorób tkanki łącznej [9]. Patogeneza pokrzywki naczyniowej wiąże się z reakcją nadwrażliwości typu III, podobnie jak w innych leukocytoklastycznych zapaleniach naczyń. Potwierdzeniem jest obecność krążących kompleksów immunologicznych, które stwierdza się u ok. 30-75\% pacjentów [4]. Pokrzywka naczyniowa najczęściej występuje u kobiet w młodym i średnim wieku [3]. Mimo że zmianom skórnym może towarzyszyć świąd (objaw typowy dla obrazu klinicznego pokrzywki), zwykle pacjenci z pokrzywką naczyniową zgłaszają uczucie pieczenia lub ból. Pacjentów z pokrzywką naczyniową można podzielić na grupę z hipokomplementemią (pokrzywkowe zapalenie naczyń z hipokomplementemią - HUVS) i grupę z prawidłowym poziomem dopełniacza (pokrzywkowe zapalenie naczyń z normokomplementemią - NUVS). HUVS ma częściej charakter układowy, a objawy pozaskórne mogą dotyczyć różnych narządów [4]. W 75\% przypadków może dochodzić do zajęcia stawów z towarzyszącym bólem, obrzękiem, sztywnością lub zapaleniem w obrębie jednego lub kilku stawów [9]. Objawy w obrębie nerek, układu oddechowego, narządu wzroku, układu pokarmowego 
Laboratory examinations may demonstrate various abnormalities, especially if there is an underlying systemic disease. Complete blood count with differential, renal function, liver enzymes, complement assessment (CH50, C3, C4, C1q and anti-C1qantibodies), and erythrocyte sedimentation rate are important laboratory examinations to be performed; occasionally hepatitis B and C virus testing, ANA panel, anti-double stranded DNA antibodies, rheumatoid factor (RF) and anti-cyclic citrullinated peptide autoantibodies are required [3]. Skin biopsy is essential in establishing the diagnosis of urticarial vasculitis. Histological examination reveals a combination of interstitial infiltrates (polymorphonuclear leukocytes, lymphocytes), leukocytoclasis, perivascular dermal hemorrhages, tissue eosinophilia and fibrinoid changes in vessel walls, while direct immunofluorence (DIF) may demonstrate depositions of immunoglobulins or C3 in blood vessels or the basement membrane zone [4].

In the context of urticarial vasculitis treatment it is important to note that antihistamines are not drugs of utmost significance. This may reflect their inability to control the inflammation caused by immune complexes [10]. In a classic paper by Mehregan et al. [4] 72 cases of urticarial vasculitis were studied. Antihistamines provided improvement in only 20 patients, while in 17 patients they were not beneficial at all. Other tested drugs included nonsteroidal anti-inflammatory drugs, oral steroids, antimalarials, cimetidine, azathioprine, cyclophosphamide and colchicine with the treatment success vs. failure being 15 vs. 10,23 vs. 4,14 vs. 12,0 vs. 4,2 vs. 2,1 vs. 1 and 0 vs. 2 , respectively. Sanchez et al. [11] reported that in 13 of 17 patients oral corticosteroids provided complete remission or decreased the severity of lesions. In a study focusing on patients with urticarial vasculitis coexisting with CTD Asherson et al. [10] observed variable responses to corticosteroids and immunosuppressants. Furthermore, in a study by Moreno-Suárez et al. [12] $(n=15) 53.3 \%$ of patients responded to the combination of antihistamines and oral corticosteroids. Other drugs were effective in $20 \%$ (rituximab or cyclophosphamide), $13.3 \%$ (colchicine) and 6.7\% (dapsone) of patients. The usefulness of intravenous immunoglobulins (IVIG) in HUVS was also reported by some authors $[13,14]$.

Our patient is interesting because of several aspects. Based on our knowledge, this is the second report in the world literature of a patient with urticarial vasculitis coexisting with myelofibrosis. We have found only one other similar case, described by Koudoukpo et al. [15], when HUVS developed in a patient with myelofibrosis associated with ET. However, in contrast to our report, the previous case concerned a patient with secondary type of myelo- i układu nerwowego stwierdza się odpowiednio u ok. $60 \%, 55 \%, 35 \%, 30 \%$ i $12 \%$ pacjentów.

Mogą również występować różne odchylenia w badaniach laboratoryjnych, zwłaszcza w przypadkach współistnienia z chorobą układową. Istotne znaczenie mają badania laboratoryjne: morfologia krwi z rozmazem, badanie czynności nerek, stężenie enzymów wątrobowych, ocena układu dopełniacza (CH50, C3, C4, C1q i przeciwciała anty-C1q) oraz OB. W niektórych przypadkach wymagane jest wykonanie badań w kierunku wirusowego zapalenia wątroby typu B i C, przeciwciał ANA, przeciwciał przeciwko dwuniciowemu DNA, czynnika reumatoidalnego (RF) i przeciwciał przeciwko cyklicznemu cytrulinowanemu peptydowi [3]. Kluczowe znaczenie dla ustalenia rozpoznania pokrzywki naczyniowej ma wycinek skóry. W badaniu histopatologicznym widoczne są nacieki śródmiąższowe (leukocyty wielojądrzaste, limfocyty), leukocytoklazja, okołonaczyniowe wynaczynienia erytrocytów, eozynofilia tkankowa oraz zmiany włóknikowate w ścianach naczyń krwionośnych. Bezpośrednie badanie immunofluorescencyjne może natomiast wykazywać obecność złogów immunoglobulin lub C3 w naczyniach krwionośnych lub w obrębie błony podstawnej [4].

Należy podkreślić, że leki przeciwhistaminowe nie odgrywają głównej roli w leczeniu pokrzywki naczyniowej, ponieważ nie mają zdolności eliminowania stanu zapalnego wywołanego przez kompleksy immunologiczne [10]. W badaniu przeprowadzonym przez Mehregana i wsp. [4] przeanalizowano łącznie 72 przypadki pacjentów z pokrzywką naczyniową. Leki przeciwhistaminowe okazały się skuteczne zaledwie u 20 pacjentów, natomiast u 17 badanych nie przyniosły żadnego efektu. Analizowano również niesteroidowe leki przeciwzapalne, doustne steroidy, leki przeciwmalaryczne, cymetydynę, azatioprynę, cyklofosfamid i kolchicynę. Leczenie poszczególnymi metodami okazało się skuteczne lub nieskuteczne $u$ odpowiednio 15 i 10, 23 i 4, 14 i 12, 0 i 4, 2 i 2, 1 i 1 oraz 0 i 2 spośród badanych pacjentów. Sanchez i wsp. [11] stwierdzili, że leczenie glikokortykosteroidami doustnie przyniosło całkowitą remisję lub zmniejszenie nasilenia zmian u 13 spośród 17 badanych pacjentów. W badaniu przeprowadzonym u pacjentów z pokrzywką naczyniową i współistniejącymi chorobami tkanki łącznej Asherson i wsp. [10] zaobserwowali zmienną odpowiedź na terapię lekami immunosupresyjnymi i glikokortykosteroidami stosowanymi doustnie. W innym badaniu Moreno-Suárez i wsp. [12] ( $n=15)$ zaobserwowali odpowiedź na leczenie skojarzone lekami przeciwhistaminowymi i glikokortykosteroidami u 53,3\% pacjentów. Inne leki wykazały skuteczność u 20\% (rytuksymab lub cyklofosfamid), 13,3\% (kolchicyna) i 6,7\% (dapson) pacjentów. W niektórych doniesieniach 
fibrosis. This patient was treated with ruxolitinib (a JAK2 inhibitor) with no improvement of cutaneous symptoms, followed by instigating prednisolone (20 mg/day) and achieving a good response. Similarly, systemic steroids also provided complete resolution of cutaneous lesions in our patient. It has to be mentioned that our patient was diagnosed with urticarial vasculitis, and not HUVS, as anti-C1q antibodies were negative (the detected serum concentration of these antibodies was $9.16 \mathrm{U} / \mathrm{ml}$, the reference norm being $<10 \mathrm{U} / \mathrm{ml}$ ).

In the past other authors have also described the association of urticarial vasculitis with hematological diseases. A study by Mehregan et al. [4] reported 6 associations in total: 2 with myelodysplasia, 1 with Hodgkin lymphoma, 1 with nonlymphocytic leukemia, 1 with acute myelogenous leukemia, and 1 with idiopathic thrombocytopenic purpura. Furthermore, Scott et al. [16] described a case of a 32-year-old woman suffering from ET and urticarial vasculitis, and Shah et al. [13] reported HUVS associated with low-grade non-Hodgkin lymphoma that was successfully treated with two cycles of IVIG (at a dose of $1 \mathrm{mg} /$ $\mathrm{kg}$ ). In addition, classic leukocytoclastic vasculitis was also observed in patients with hematological malignancies $[17,18]$.

\section{CONCLUSIONS}

Urticarial vasculitis is a cutaneous disorder observed occasionally in dermatological practice that may be associated with multiple factors, including hematological diseases.

\section{CONFLICT OF INTEREST}

The authors declare no conflict of interest. wskazywano także na skuteczność dożylnych immunoglobulin (IVIg) w HUVS [13, 14].

Przedstawiony przez nas przypadek jest ciekawy z kilku względów. Według naszej wiedzy jest to drugi opisany w piśmiennictwie przypadek pokrzywki naczyniowej współistniejącej z włóknieniem szpiku. W piśmiennictwie jest tylko jeden podobny przypadek, analizowany w pracy Koudoukpo i wsp. [15], w którym stwierdzono HUVS u pacjenta z włóknieniem szpiku z towarzyszącą nadpłytkowością samoistną. W przeciwieństwie do opisanego przez nas przypadku, u pacjenta z przywołanej pracy rozpoznano jednak wtórną postać włóknienia szpiku. Chory był leczony ruksolitynibem (inhibitorem JAK2), jednak leczenie nie przyniosło poprawy w zakresie zmian skórnych. Po wdrożeniu terapii prednizolonem (20 mg/ dobę) uzyskano dobrą odpowiedź. Podobnie, ogólnoustrojowe leczenie steroidami spowodowało całkowite ustąpienie zmian $\mathrm{u}$ opisywanego przez nas pacjenta. Należy przy tym zaznaczyć, że u naszego pacjenta ustalono rozpoznanie pokrzywki naczyniowej, a nie HUVS, ponieważ wynik badania w kierunku przeciwciał anty-C1q był ujemny (stężenie przeciwciał w surowicy wyniosło 9,16 U/ml przy wartościach referencyjnych $<10 \mathrm{U} / \mathrm{ml}$ ).

Inni autorzy również opisali związek pokrzywki naczyniowej z chorobami hematologicznymi. W badaniu Mehregan i wsp. [4] stwierdzono występowanie 6 przypadków współistnienia z tymi chorobami: 2 z mielodysplazją, 1 z chłoniakiem Hodgkina, 1 z białaczką nielimfocytową, 1 z ostrą białaczką szpikową i 1 z idiopatyczną plamicą małopłytkową. Ponadto Scott i wsp. [16] przedstawili przypadek 32-letniej kobiety z nadpłytkowością samoistną i pokrzywką naczyniową, a Shah i wsp. [13] przypadek HUVS w przebiegu chłoniaka nieziarniczego niskiego stopnia, skutecznie leczonego dwoma cyklami IVIG (w dawce $1 \mathrm{mg} / \mathrm{kg}$ m.c.). Klasyczne leukocytoklastyczne zapalenie naczyń obserwowano także u pacjentów z nowotworami hematologicznymi $[17,18]$.

\section{WNIOSKI}

Pokrzywka naczyniowa jest rzadko spotykanym w codziennej praktyce dermatologicznej schorzeniem skóry, które może się wiązać z licznymi zaburzenia$\mathrm{mi}$, m.in. chorobami hematologicznymi.

\section{KONFLIKT INTERESÓW}

Autorzy deklarują brak konfliktu interesów.

\section{References \\ Piśmiennictwo}

1. Arber D.A., Orazi A., Hasserjian R., Thiele J., Borowitz M.J., Le Beau M.M., et al.: The 2016 revision to the World Health Organization classification of myeloid neoplasms and acute leukemia. Blood 2016, 127, 2391-2405.

2. Tefferi A.: Primary myelofibrosis: 2014 update on diagnosis, risk-stratification, and management. Am J Hematol 2014, 89, 915-925. 
3. Hamad A., Jithpratuck W., Krishnaswamy G.: Urticarial vasculitis and associated disorders. Ann Allergy Asthma Immunol 2017, 118, 394-398.

4. Mehregan D.R., Hall M.J., Gibson L.E.: Urticarial vasculitis: a histopathologic and clinical review of 72 cases. J Am Acad Dermatol 1992, 26, 441-448.

5. Kulthanan K., Cheepsomsong M., Jiamton S.: Urticarial vasculitis: etiologies and clinical course. Asian Pac J Allergy Immunol 2009, 27, 95-102.

6. Moulard O., Mehta J., Fryzek J., Olivares R., Iqbal U., Mesa R.A.: Epidemiology of myelofibrosis, essential thrombocythemia, and polycythemia vera in the European Union. Eur J Haematol 2014, 92, 289-297.

7. Mesa R.A., Schwager S., Radia D., Cheville A., Hussein K., Niblack J., et al.: The Myelofibrosis Symptom Assessment Form (MFSAF): an evidence-based brief inventory to measure quality of life and symptomatic response to treatment in myelofibrosis. Leuk Res 2009, 33, 1199-1203.

8. Zuberbier T., Aberer W., Asero R., Bindslev-Jensen C., Brzoza Z., Canonica G.W., et al.: The EAACI/GA(2) LEN/EDF/ WAO Guideline for the definition, classification, diagnosis, and management of urticaria: the 2013 revision and update. Allergy 2014, 69, 868-887.

9. Zuberbier T., Maurer M.: Urticarial vasculitis and Schnitzler syndrome. Immunol Allergy Clin North Am 2014, 34, 141-147.

10. Asherson R.A., D'Cruz D., Stephens C.J., McKee P.H., Hughes G.R.: Urticarial vasculitis in a connective tissue disease clinic: patterns, presentations, and treatment. Semin Arthritis Rheum 1991, 20, 285-296.

11. Sanchez N.P., Winkelmann R.K., Schroeter A.L., Dicken C.H.: The clinical and histopathologic spectrums of urticarial vasculitis: study of forty cases. J Am Acad Dermatol 1982, 7, 599-605.

12. Moreno-Suárez F., Pulpillo-Ruiz Á., Zulueta Dorado T., Conejo-Mir Sánchez J.: Urticarial vasculitis: a retrospective study of 15 cases. Actas Dermosifiliogr 2013, 104, 579-585.

13. Shah D., Rowbottom A.W., Thomas C.L., Cumber P., Chowdhury M.M.: Hypocomplementaemic urticarial vasculitis associated with non-Hodgkin lymphoma and treatment with intravenous immunoglobulin. Br J Dermatol 2007, 157, 392-393.

14. Yamazaki-Nakashimada M.A., Duran-McKinster C., Ramírez-Vargas N., Hernandez-Bautista V.: Intravenous immunoglobulin therapy for hypocomplementemic urticarial vasculitis associated with systemic lupus erythematosus in a child. Pediatr Dermatol 2009, 26, 445-447.

15. Koudoukpo C., Jachiet M., Zini J.M., Andreoli A., Pinquier L., Rybojad M., et al.: Urticarial vasculitis associated with essential thrombocythaemia progressing to myelofibrosis. Ann Dermatol Venereol 2014, 141, 773-776.

16. Scott A.D., Francis N., Yarranton H., Singh S.: Urticarial vasculitis associated with essential thrombocythaemia. Acta Derm Venereol 2014, 94, 244-245.

17. Yadav B.S., Sharma S.C., Kapoor R.K.: Paraneoplastic leukocytoclastic vasculitis in chronic lymphoid leukemia. J Cancer Res Ther 2006, 2, 206-208.

18. Gulati S., Patel N.P., Swierczynski S.L.: Vasculitides associated with haematological malignancies: a case-based review. BMJ Case Rep 2012, 2012, bcr2012007123.4

Received: 7.09.2017

Accepted: 8.10.2017

Otrzymano: 7.09.2017 r.

Zaakceptowano: $8.10 .2017 \mathrm{r}$.

How to cite this article

Reszke R., Reich A.: Urticarial vasculitis coexisting with primary myelofibrosis - a case report. Dermatol Rev/Przegl Dermatol 2017, 104, 663-671. DOI: https://doi.org/10.5114/dr.2017.71838. 